12th LUMEN International Scientific Conference Rethinking Social Action. Core Values in Practice | RSACVP 2019 | 15-17 May 2019 | lasi - Romania

\title{
Access to Education for People with Special Needs in Algeria
}

\author{
Rachid BESSAI
}

https://doi.org/10.18662/lumproc. 183

How to cite: Bessai, R. (2019). Access to Education for People with Special Needs in Algeria. In C. Ignatescu (ed.), 12th LUMEN International Scientific Conference Rethinking Social Action. Core Values in Practice, 15-17 May 2019, Iasi - Romania (pp. 1-12). Iasi, Romania: LUMEN Proceedings. https://doi.org/10.18662/lumproc.183 


\title{
Access to Education for People with Special Needs in Algeria
}

\author{
Rachid BESSAI $^{1}$
}

Abstract

This study aims to address the report of disabled children in school, a subject which has become in recent years a special concern and attracted education specialists' attention and created an international debate related to the policy of taking in charge this category of children. Such a problem calls today to question about disabled children's schooling in Algeria and the mechanisms of their inclusion at school. Many such questions are raised to serve the study's objective as: do children with disabilities have access to education in our country? How can we accompany these children in school? Is their inclusion feasible after giving real hope to their parents? And what is the role of associations in this process? To respond to this series of questions, which refract well the aspect of inclusion in the Algerian actuality, we will proceed to a sociological reading of the statistics put forward by the Ministry of National Solidarity through its different structures in relation to the disabled children schooling. The aim will also be to show the state of the arts of takings such children in charge through diverse associations' actions.

Keywords: childhood; disability; inclusive education; Association; specific needs.

\section{Introduction}

The question of children with disabilities and its relation to school is a strong reality of the current time; it is significant of a deep, collective and even civilizing evolution. This reality occurs at two levels: that of disabled children that are related to the way others look at them-which is actually changing, at the same time that of the space arrangement that needs to be made within society. And that of the whole society, led by a new attention to

\footnotetext{
1 Lecturer PhD, Faculty of Human and Social Sciences, University of Bejaia, Algeria, bessairachid@yahoo.fr 
disability, to best take into account the difficulties disabled people face [8:55]. The question of disabled children and the school took, in recent years, a special highlight in the concerns of specialists in education. Of course, this interest is not modern, but current approaches stand out and actually reflect a significant change at the level of support policies. The issue of the complex relationship between the family, the disabled child and school made so the subject of lengthy discussions between researchers who continue to fuel a number of seminars, symposia and conferences across the world. In Algeria, although there is a large number of legal provisions to ensure the right to education of all children without discrimination, but a huge delay is witnessed in terms of taking care of disabled children in real situations. Indeed, there is a lack of devices for their inclusion in the Algerian educational system, only aid services are limited to a few public institutions under the supervision of the Ministry of National Solidarity. In short, things seem more theoretical than practical, because the intervention process has taken a serious delay compared to the evolution of things in the field. It should be noted that, in this country, the absence of a great tradition of research on family practices of education and schooling of disabled children makes the academic support process more complex. We will try to deal with this problem through the following: firstly, emphasis will be put on the notion of handicap and try to suggest a new concept. Then we will talk about inclusive education of children with special needs, precisely is it possible after giving real hope to their parents? We will also address the Algerian experience in terms of providing support to this category, while at the end we will show the role of associations in the process of inclusive education.

\section{Towards a new conception of handicap}

If we search for the classical definition of the term disability we find that it appeared at the end of the 19th century. Everyone knows the conventional explanations of the Anglo-Saxon origin of the term "hand in cap" which means hand in the hat and the use of even the odds of the horses in horse races in handicapping them additional weight [22: 63], but the term appears for the first time in an official text in the Act of 23 November 1957 on the disabled workers, disabled meaning here infirm. The Robert dictionary of the French language [2] considers that the term disability that has replaced other words as invalid, abnormal and inappropriate, is one of 'these social cuts masking the harsh realities', so the concept disability is defined as: "They say they are disabled because they 
suffer as a result of their physical, mental, temperamental State or their social situation, problems that are for them to "disabilities" [23: 45] i.e. weaknesses and easements particularly compared to normal, it is defined as the average of the capabilities and opportunities of most individuals living in the same society'. This definition is more holistic and extensive that applies to difficulties of the physical, mental and social kinds. The notion of disability seems more resulted from pragmatism and convenience utility rather than scientific knowledge of clinical description. This concept may even be an epistemological obstacle that hinders the process of knowledge and gives it a kind of "false clarity" [14: 114]. The handicap is therefore not an objective reality that science can study. Some specialists tackle the concept of disability as being "unsuitable" i.e. the State of inadequacy of the subject in the community or the inappropriate person who suffers from an environment not conform to its needs [6: 88]. Through this conceptual definition, we notice that is the concept of disability is not at the level of an attempt of semiotic classification. It seems that we score another perspective in the traditional way to consider the disability, which cannot be limited to categorization, or an objective clinical reality. This definition of a disabled person marks the transition between the classical design of disability and its new meaning. This classic design of disability invites us to revise our way of approaching things and people, we are also invited to separate in our attitudes toward people with disabilities which is the domain of the pathology and that is a measurable and attaching reality, and what is a social consequence of this pathology. Research made by who, 1985, has allowed to isolate three distinct concepts: impairment, disability and handicap.

1 - The deficit: reference to any loss or abnormality on an organ or a psychological, physiological or anatomical function.

2 - Inability: is the quantitative or qualitative absence or reduction of the ability to act, this reduction may be partial or total of the ability to perform an activity in a way considered to be normal. Inability is the functional aspect of disability.

3 - Disability: reference to the sum of the enduring frustrations that result for a person of impairment or disability resulting in the total or partial impossibility of a very normal role. Under the new definition of disability we see that the old design of the concept is less accurate than today, because disability is defined as the discrepancy between the performance or status of a person and the hopes and the prospects of this person or group to which it belongs. The disadvantage is the situational aspect of disability and that is where the radical distinction takes place between the old conceptions which considers disability as: physical, sensory and mental, a class of the nosography and nowadays that puts into perspective this notion to the level 
of a situation. Because it is now essentially handicap situation: physical dependence, economic dependence, no social integration situation [5: 77]. We can illustrate this idea through the following example: "two people lose one and the other the ring finger and the little finger of the left hand in an accident." One is roadman in a municipality, the other is violoncellist. The deficit and failure are the same. On the other hand, the professional situation of each person is compromised for the violoncellist who might lose his job and more slightly the roadman who keeps and can continue to enjoy his social integration. One realizes that disability is not an absolute given, but can be reduced depending on the environment. Yet, one should consider the existence of some exceptions, because there may be handicaps without inabilities, impairments without handicap, or disabilities without deficit. The use of the trilogy is not necessarily required to demonstrate that a wellcompensated for deficit does only minimal disability. Hearing loss as an example demonstrates this idea because of hearing disorders resulting in an inability to listen can be corrected by an apparatus that limits the inability. Therefore, the new conception of disability first requires us to change our view of the disabled person and then our action. On the forefront, it seems important to think that the disabled person's situation is not only assessed according to its organic or functional aspects, but also according to his family environment, according to his social role, according to what he is able to achieve depending on the particular environment he belongs to [3: 91]. Secondly, and once the analysis of his rapports is made, action which seems to contribute to achieve the best results, is one that combines the resulting benefits both the reduction of deficiency, disability and handicap. So it is this level of action on disability that opportunities for integration are settled, it permits to solve the problem of segregation, and hence researching best benefits, whether in a workplace or in another, does not have the effect of removing all the inconveniences. Any human solution is usually a combination of advantages and disadvantages. The way one treats them so that they do not prevail on them, it is to engage in a process of project.

\section{School inclusion of a disabled child}

The concept of 'inclusive education' refers to an educational system that takes into account individual needs in teaching and learning of all children in vulnerable situations; children with disabilities, street children, children belonging to ethnic minorities, children from families nomads/refugees, etc. Inclusive education does not raise the problem of which children with what types of disabilities can be integrated in regular 
class? But how must we adapt the aspects of school life so that inclusion is possible? Two approaches can be distinguished:

\subsection{The child specific needs-centered approach}

This approach focuses on the child's needs, so that it is not up to the pupil to adapt to the ordinary school environment, but to the school environment to adapt to the pupil, in order to offer the best learning conditions: the child is the core of the inclusion process surrounded by support not necessarily to school services [21: 102]. Several elements (health, recreation, transport, etc.) contribute to the success of inclusive education.

\subsection{The factors surrounding the child approach}

This approach focuses on the factors surrounding the child so that inclusion requires interaction between the different services of the inclusive community: ordinary as services: education, health, leisure, are linked to the basic needs of the child. They must be perfectly accessible. Services specific to the image of early intervention and special education are designed to meet the complex needs of children of severe disabilities [19: 62]. As the SLA (student life assistants) support services: facilitate the participation of the child in daily activities. The SLA is a person trained to provide human assistance, responding to the specific needs of children with disabilities to the integrated school.

(a) Support function: allows the child to be autonomous in communication.

(b) Educational function: allows the student to perform an exercise when he encounters difficulties related to his disability.

(c) Communication function: which promotes the interaction of the child with other actors (teachers - professionals, etc.).

\section{The Algerian experience of disabled children care services}

Concerning the Algerian support experience, we can say; although there is a large number of legal provisions ensuring the right to education of all children without discrimination, but we notice that there exists a considerable delay for support of disabled children, mainly in schools. Civil society is not sufficiently equipped and structured to meet the challenges of inclusive education. According to the Algerian national solidarity Ministry published in 2014. We notice that: 630,000 children with disabilities, 
including only $125,000(20 \%)$ are supported by the following organizations: 104000 by the National Education -14532 by specialized public centers 5000 network and 1452 by private integrated classes. Despite these Welcome Center, many parents find it difficult, they are faced with indifference sometimes displayed on the part of the institutions that are supposed to support, they are left alone, every back-to-school period, the same pain, the same feeling for the parents, they undertake actions by themselves to provide the necessary health care, specialized support to their children. Others knock on several doors before they can find a place for their children, besides more than 9,000 disabled children are still waiting for support according to the same source.

\section{Is it possible to integrate the disabled child at school?}

Integration is not a simple insertion in the school environment; it assumes the accompaniments without which a student with a disability can neither have access to school life, nor to the provided knowledge. This support usually exceeds the only means of national education and involves the use of a partnership with the services of social affairs and health. The integration also is various: far from being unique, it represents a variety of situation, depending on the nature and severity of the disability, since the very partial integration (from, a specialized institution), until the full individual integration in a regular class, going very often through the necessary provisional groupings as school integration classes [10: 213]. Integration after all is, regardless of the situations, always individual, because it is the measure of both the capacities and the potentialities of each child at a given moment. Is the school integration of children and adolescents with disabilities a current fashion? Some say, especially among those who think it is an illusion to welcome these young people into ordinary classes, arguing that there are still many specialized institutions created specifically to welcome them [11: 47]. Others believe that integration, which is the purpose of any special education, can also be a way to prepare the best possible [7: 156]. In fact, as in the field of the integration of people of foreign origins, the integration of people with disabilities is most of the time, a movement of opinion in their favor, since everyone is for integration, as long as it is a way of participation in the dominant and fundamental values of our society. The issue of school integration of disabled children arouses collaboration of many actors who can play several roles, very important for the success of integration, because this last go through the support provided by specialists, which is necessary for them. This does not necessarily mean that these 
supports are physically and functionally integrated into the school - no doubt an ideal solution - probably best solution - but that the function of coordination and synthesis that integrates therapeutic, educational and pedagogical professionals in the project must necessarily be somewhere a jurisdiction [2: 102]. In short, if the child is integrated in the ordinary school, the concern that should worry the project partners permanently does not limit himself to preserving all the benefits he would receive if he were placed in a specialized institution, but must ensure that the action on the child is not shared, or that is exercised, and that the synthesis function continues to operate [18: 136]. For this we must distinguish between two types or two ways of integration: integration with integrated support at school and integration with support from outside the school.

\section{The role of parents in the school inclusion project}

Parents can play a very important role in the inclusion of children with disabilities in school, some think of the role of parents as a duty, a necessary initiative for the success of the inclusion project, because the responsibility can be shared by several partners [12: 152]. When the family of a disabled child opts for schooling in an ordinary environment, the reasons that lead them to express this application may cover several meanings: 1 . It can be a situation of leak from disability, so parents sometimes fail to meet their responsibilities. Integrate is not normalize, is precisely to recognize the difference. However when the application integration is presented with the current wording: "I want that it is treated exactly the same way as other children", this meant not a negation of the handicap, but recognition of the service of the school. In fact, most parents prior to the inclusion of their children do not know that the school can provide a project approach. They are often surprised when we teach them, though they believed that inclusion required only little new energy, and we further asked them less to take an active part in its realization [13: 126]. 2 - In some cases, parents do not claim absolute right to inclusion, they are aware that there are conditions that turn around the child's skills and abilities of the school environment. Very often, they are decided to undertake steps with several schools, looking for that school where it is the richest and the less reluctant [17: 255]. We should say that more parents seem to be willing to get involved in transport, in the diverse tasks, because they were well accompanied in their first steps by a parents association. Demand may come from parents who have no preferences marked for inclusion which they are not a priori unconditional. They have heard of their rights and of the existence of the dual network of support. Quite often, the demand for care is not 
achievable other than through inclusive education [16: 78]. Whatever the meaning of these initial applications is, there are two attitudes not recommended for the teaching staff of the institution where inclusion is requested. It is that of outright refusal that can only strengthen in the minds of parents the idea of exclusion that they live painfully s. It is on a different level, which is to host, may be of advantage to tolerate the child in an undifferentiated way not to say indifferent. In this case, no need to talk about evaluation project [15: 21]. It is important that someone explains to requesting parents the choice of inclusive education is not a panacea that can solve everything. It can solve the problem of impairment and disability, is something else and, on this plan, school has not this ability especially if parents turned their back on specialized institutions and frustrate the child to get the specific care and help as part of his rights. If the family declares itself ready to advance on the difficult path of mainstream education, we must give them every opportunity to participate fully in the project. In which way? By invitation first to the meetings of the educational team [20: 118]. Experience has largely shown that when parents are involved in the project process, the latter is more likely to succeed. Too often when parents receive the follow-up document with the "seen and read" formula under which they must sign, which means that they only become aware of it at that time, they have impression that they are being held out of concentration [9:238]. When the misunderstanding of the reality of the handicap by some parents double leaks on the part of the concerned services which cannot offer anything else than two half-days a week, what perspective, what project is left for the selected child as a hostage of the incomprehension of adults? So, the question often arises whether parents should attend the integration of the integration team meetings? Parents in specialized institutions do not have to be surprised not to be invited to all the synthesis meetings. If the institution associates them to the individual project asking texts, by inviting them to the synthesis meetings, it is very well damage. It is the same for school integration. The day everyone understands that parent involvement is not a hindrance to completing an inclusion project or specialized orientation but an additional asset to the success of this project, a major step will be made. For the moment, only those who were able to put their philosophy with their actions made it.

\section{The role of associations in the process of inclusive education}

Work that deserves to be mentioned is that of associations, which have begun, a dozen years ago, a long-term fight undergone remarkably 
through their work on the ground. We can give the example of 03 projectsholder associations of school inclusion:

\subsection{Association for mentally maladjusted children 'challenge' of Bejaia}

This association in collaboration with the Embassy of France in Algeria, set up in 2017 a device support and accompaniment of the children with disabilities in schools, whose goal is to move towards a more inclusive school, more adapted to the specific needs of the child. This project is supervised by a multidisciplinary team composed of psychologists, specialized clinicians-psychologists, school-pathologists, specialized educators. They intervene by raising awareness among directors, teachers and parents. Its record is remarkable since: 351 schooled children with disabilities are supported in 42 facilities, three cells of listening and accompaniment were created in three municipalities in the region, where there are more people with disabilities.

\subsection{Association of parents of CP children (cerebral palsy) of Setif}

The project "Education for all: towards the inclusion of children with disabilities in the Algerian educational system", initiated by Handicap International in partnership with the association led a territorial investigation in order to identify the obstacles to the education of children with disabilities in school. With the support of the Director of Education of the wilaya, accompaniment services to the schooling of these children were created for the training of auxiliary school life (ASL). This has allowed the association to form the ASL to intervene with ordinary schools as psychologists and speech therapists as part of pre-employment. The goal of the project was also to accept these ASL in schools after being almost an impossible procedure and even taboo in some localities. In the end, 45 children with disabilities were accompanied and integrated into the school.

\subsection{Association of the disabled and their friends (AHLA) - Tizi- Ouzou}

In order to meet the specific needs of disabled children in school, this association with the support of the European Union has set up a mobile device to support school composed of a multidisciplinary team, working at the daily on various aspects of these support. The goal of this project is to offer comprehensive support of the child academically. The interventions of 
the team differ according to their specialties and the needs of the child. This device judged positive by the association allows: an improvement in the quality of access to learning to $80 \%$ of children with disabilities, and the creation of a psycho-pedagogical center for children with intellectual disabilities offering psychological care for parents with disabled children.

\section{Conclusion}

Although the equality of rights and opportunities, participation and citizenship of persons with disabilities strengthen action to support disabled students' education, it must be said that the situation is not often comfortable for this category of people. The law says that any child, any teenager with a disability or disabling health disorder is enrolled in the nearest school to his home which is his institution of reference [1: 55]. But the least that can be said is that our school is more demanding, has little tendency to look at the difficulties it creates for children. This is why we must also know, if needed, how to protect children with disabilities in school. The task of the school cannot, therefore, be reduced to accommodate children with disabilities. It must, if not to protect them, but at least not to make their lives too difficult. Moreover, we are convinced, that the access to schooling for children with special needs must be strengthened and defended and that the school inclusion process is possible, only it requires courage, will and professionalism. Everyone has to get involved: the school must seek liberal partners and specialized institutions to provide real support to the policy of support. Associations of their side must continue their fight to change mentalities, to make sure that the school adapts to the child and that this fight is that of the whole society, because even if the means are missing, but it is necessary to know that nothing is impossible.

\section{References}

[1] Ballarin J. Enfants difficiles, structures spécialisées [Difficult children, specialized structures]. Paris, France: Nathan; 1994.

[2] Berger M. Entretiens familiaux et champ transitionnel [Family conversations and transitional field]. Paris, France: PUF; 1987.

[3] Bonjour P, Lapeyre M. Handicaps et vie scolaire [Disabilities and school life]. Paris, France: Chronique Sociale; 1994.

[4] Dictionnaire de la langue française [Dictionary of the French language]. 2ème édition. (1993). Paris: Le Robert; 1993. 
[5] Dore R, Wagner S. Réussir l'intégration scolaire [Successful school integration]. Paris, France: Logiques; 1996.

[6] Dubar C. La socialisation: Construction des identités sociales et professionnelles [Socialization: Building social and professional identities]. Paris, France: Armand Colin; 2000.

[7] Fuster Ph, Jeanne Ph. Enfants handicapés et intégration scolaire [Children with disabilities and school integration]. Paris, France: Armand Colin; 1996.

[8] Gillig JM. Intégrer l'enfant handicapé à l'école [Integrate the disabled child into school]. Paris, France: Dunod; 1999.

[9] Houzel D, Catoire G. La famille comme institution [The family as an institution]. Lyon, France: Apsygée; 1994.

[10] Jeanne P, Laurent JP. Enfants et adolescents handicapés [Children and adolescents with disabilities]. Paris, France: ESF; 1998.

[11] Lantier N. Enfants handicapés à l'école [Disabled children at school]. Paris, France: L'Harmattan; 1994.

[12] Lemaire J-G. Le couple, sa vie, sa mort [The couple, its life, its death]. Paris, France: Payot; 1981.

[13] Lemaire JG. Famille, amour, folie [Family, love, madness]. Paris, France: Païdos/Centurion; 1989.

[14] Martin P, Papier C, Meyer J, Sand EA. Le handicap en question : des familles face à la découverte du handicap et à l'accompagnement du jeune enfant à domicile [The handicap in question: families facing the discovery of disability and the accompaniment of young children at home]. Paris, France: CTNERHI; 1993.

[15] Neyrand G. L'enfant, la mère et la question du père: un bilan critique de l'évolution des savoirs sur la petite enfance [The child, the mother and the question of the father: a critical assessment of the evolution of knowledge on early childhood]. Paris, France: PUF ; 2000.

[16] Pelicier Y, Thuilier G. Édouard Séguin: L'instituteur des idiots [Édouard Séguin: The teacher of idiots]. Paris, France: Économica; 1980.

[17] Pelicier Y, Thuilier G. Un pionnier de la psychiatrie de l'enfant [A pioneer of child psychiatry]. Paris, France: La Documentation Française; 1996.

[18] Racamier PC. Une psychanalyse sans divan [Psychoanalysis without a couch]. Paris, France: Payot; 1993.

[19] Sausse S. Le miroir brisé: L'enfant handicapé et sa famille [The broken mirror: The handicapped child and his family]. Paris, France: Seuil; 1996. 


\section{Rachid BESSAI | Lumen Proceedings 9 | RSACVP2019}

[20] Simon J. L'intégration scolaire des enfants handicapés [School integration of children with disabilities]. Paris, France: PUF: 1988.

[21] Terral D. Prendre en charge à domicile l'enfant handicapé [Take charge of the handicapped child at home]. Paris, France: Dunod; 2002.

[22] Vial M. Les enfants anormaux à l'école, aux origines de l'éducation [Abnormal children at school, the origins of education]. Paris, France: Armand Colin; 1990.

[23] Zribi G. L'accueil des personnes gravement handicapées [Reception of severely disabled people]. Paris, France: E.N.S.P; 1994. 